\title{
Inflation, Unemployment, and Hayek
}

\author{
ROGER W. SPENCER
}

傹 N THESE times of high unemployment and rising price levels, one looks to the leaders of the economics profession for analysis and solutions. One possible candidate, who has investigated these problems in detail, is Friedrich August von Hayek. Hayek was awarded a share of the Nobel Prize for Economics last autumn. Born in 1899 in Austria, Hayek is probably better known in Europe than in the United States. After spending his formative years studying economics and law in Austria, he moved to England in 1931 and then on to the University of Chicago in 1950. Hayek accepted a chair at the University of Freiburg in Germany in 1962. Several years later he returned to Austria, where he now lives.

After teaching and publishing extensively in the economics field during much of the first forty years of his life, Hayek became more interested in political and social developments. In fact, he is best known for his The Road To Serfdom which projected a dim future for capitalistic societies, given the steady encroachment of government into all phases of private life. That book, plus his participation in the founding of the Mont Pélèrin Society in 1946, placed Hayek in the front ranks of laissez-faire advocates throughout the world.

There was a time, specifically during the 1930s, when Hayek and John Maynard Keynes were intense rivals for the attention and leadership of the economics profession.2 The obvious problem in those (perhaps simpler) days was unemployment alone, and any analysis, such as Hayek's, which also included the likelin hood of a rising price level, was doomed to rejection. Keynes emerged the clear winner; his analysis of "inadequate" aggregate demand and prescription of stepped-up govermment spending were adopted by all capitalistic nations by the 1940 s. From that time on, active govermmental intervention to secure full

1Friedrich A. Hayek, The Road to Serfdom (Chicago: Uni versily or Chicago Press, 1944 ).

2. . 琵 is hardly remembered that there was a time when the new theories of Hayek were the princinal rival of the new theories of Keynes." Jom Hicks, Critical Essays In Monetary Theony (London: Oxford Unversity Press, 1967), p. 203. employment became the chief economic obligation of the leaders of the western world.

Today, Keynesian economic principles are being questioned more than at any time in the past thirty years. Economists are seeking new explanations and some have begun to look in the direction of Professor Hayek. This article is devoted to presenting and interpreting Hayek's analysis of inflation and unemployment.

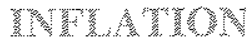

We discuss the iratation issue first because Hayek took the view that an extended period of rising prices would likely lead to a serious recession or depression. A concise explanation of this hypothesis was advanced in Chapter 21 of Hayek's book The Constitution of Liberty. ${ }^{3}$ This chapter, entitled "The Monetary Framework", summarized a good deal of Hayek's economic analysis developed during the preceding forty-year period.

\section{Q}

The chief cause of intlation, Hayek wrote, is govermmental control of the money supply. ${ }^{4}$ As the govm ernment endeavors to provide more services, it tends to run up more debt. The increase in its own debt prompts govermment to take a more active interest in national financial matters - the creation of money, in particular. Hayek reasoned that as long as the govermment can avoid extensive debt financing, it is possible to maintain a completely free and independent monetary system. Increases in the money supply, which stimulate aggregate demand, constitute the underlying source of inflationary pressures. It is not a

3F. A. Hayek, The Constitution of Liberty (Chicago: The University of Chicago Press, 1960).

tIn Hayek's words, "with yovermment in control of monetary policy, the chief threat in this field has become infation. Governments everywhere and at all times have been the chief canse of the depreciation of the currency. Though there have been occasional prolonged falls in the value of a metallic money, the major inflations of the past have been the result of govemments either diminishing the coin or issung excessive quantities of paper money." lbid., pp. 32m-328. 
conscious desire of the government to foster inflation. However, short-run political expediency and guarantees of full employment and assorted other amenities of life for all citizens make a growing government, expanding money supply, and inflationary pressures virtually inevitable. The assorted amenities include social security programs, rent and food subsidies, and legislation designed to put floors under wages and ceilings on consumer prices.

Elsewhere in The Constitution of Liberty, Hayek specifically singled out labor unions for their part in fostering inflation and unemployment. It is his contention that by permitting unions to force up wages, the government is put into the position of validating the wage-price pressure through money supply increases, or facing general unemployment by faling to validate the union action.

Besides curbing government and union power, Hayek's solution to rising price levels involves stabilizing the rate of growth of the money supply. A rule of some sort, which recognizes the inexact relation between monetary policy actions and changes in the price level, is considered desirable because it lessens inflationary pressures and removes monetary policy actions as a source of uncertainty to private decision makers. The lessening of uncertainty has long been of interest to Hayek, especially with regard to the free market economy. ${ }^{5}$

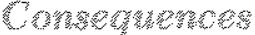

What could we expect from growing inflationary pressures? Writing during the period of relative price stability in the late 1950s, Hayek described a number of events (although he did not list them) which accompany the onset of inflation. The following is an interpretation (and only an interpretation) of his view of these events, many of which were later realized:

(1) At first, virtually all firms enjoy increased profits because the jump in prices is not anticipated. Since most of their liabilities are contractually fixed in price (for a time) and their assets are not, the rise in asset prices enhances firms net worth. Thus, in a rising market, as evidenced during the long expansion of the 1960s, profits expand and relatively few firms fail.

5F. A. Hayek, "The Use of Knowledge in Society," The American Economic Revicw (September 1945). In this article, Hayek wrote about the capacity of a free market economy to lessen uncertainty via the transmission of information which occurs as individual transactors make demand and supply decisions. Hayek is credited with being one of the early contributors to the current cost-of-information approach to micro and macroeconomic analysis.
(2) Inflation encourages debt - private as well as public. With growing incomes, people seem to be less reluctant to take on debt than at other times. Whatever one's view of the desirability of private debt, there can be little doubt that it has escalated rapidly in recent times. Private debt increased 300 percent over the past fifteen years. Public debt about doubled over this period, while that part of the public debt held by the Federal Reserve - which directly inflates commercial bank reserves and the money supply - approximately tripled.

(3) Real costs, profits, and income become difficult to ascertain. Price movements act as a veil concealing the true course of important economic variables. Recent efforts to uncover the values of "real" interest rates, "real" money supply, "real" profits and the "real" inventory situation suggest the accuracy of this observation.

(4) Progressive taxation, coupled with rising prices, affects investment adversely. It is difficult to show that investment growth has slowed over the past fifteen years, or that progressive taxation might have contributed to any such slowing. There is evidence, however, that profits have slipped in recent years and it is possible that taxes were partially responsible. Quite likely, the stimulative effects of unanticipated inflation on profits in the early 1960 s were later reversed as price anticipations began to catch up with reality.

(5) Sliding scale contracts emerge. These are both a cause and a consequence of continuing inflation. Besides the growth in the number of union workers whose wages are altered monthly by changes in the consumer price index, social security payments have added over 30 million people to the list of individuals whose income is directly adjusted to changing price levels.

(6) Over an extended period, the unemployment rate accompanying stustained inflation is no lower than in the absence of sustained inflation. In Hayek's words, "The reasonable goal of a high and stable level of employment can probably be secured as well as we know how while aiming at the stability of some comprehensive price level." Inflation may initially contribute to a lowering of the unemployment rate below what it would otherwise be, but after inflationary expectations catch up with reality, this is no longer the case. In other words, this means that the Phillips curve does not exist in the usually hypothesized "rounded - L"

6Hayek, The Constitution of Liberty, p. 337. 
Shape. Events of the past few years give credence to this hypothesis. ${ }^{7}$

(7) Inflation leads to more governmental control. Control is difficult to quantify, but the steady rise in all government employment relative to total employment, in govemment spending relative to total spending, and the recent price-wage control experience are all suggestive of increased control.

(8) If prices do not continue to rise at an accelerating rate, a serious recession or depression is inevitable. "Once it [inflation] has continued for some time, even the prevention of further acceleration will create a situation in which it will be very difficult to avoid a spontaneous deflation." In $1973-74$, a serious recession occurred despite continued acceleration of price increases. Just what is the relation of the recent increase in unemployment to Hayek's conjectures is not clear. For one thing, Hayek was vague in his later writings concerning the specific mechanism which would produce unemployment. For that reason, it may be profitable to turn to earlier analysis in which he spelled out in more detail his beliefs regarding the emergence of unemployment.

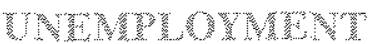

Hayek advanced a prices-unemployment argument in the 1930s which was derived largely from his version of the concept of "forced savings". A brief summary of the argument follows.

Starting from full employment, let us suppose there occurs a rise in bank credit to firms. The rise in such credit is accompanied by a fall in the market rate of interest below the "natural" rate." The additional

\footnotetext{
"See the Prices and Unemployment chart of Darry $R$. Francis, "Inflation, Recession- What's a Policymaker To Do?" thi Review (November 1974), p. 6 for an indication of the failure of this relation to assume the rounded-1, shape.

8 Hayek, The Constitution of Liberty, p. 332.

"Hayek's most specific "forced saving" ideas can be found ir Prices and Production (London: George Rontledge \& Sons, Ltd., 1946). See also F. A. Hayek, Monetary Theory and The Trade Cycle, trans. N. Kaldor and H. M. Croome (London: Jonathan Cane, 1933), and Profits, Interest and Incestment and Other Essays on the Theory of Industrial Fluctuations (London: George Routledge \& Sons, Ltd., 1939) for elaboration. The concept of forced saving, popular with numerous classical and neoclassical economists, can be traced at least as far back as Richard Cantillion, a Physiocrat, writing between 1730 and 1734. See Roger W. Spencer and Williarm P. Yohe, "A Historical Analysis of the 'Crowding Ont' of Private Expenditures by Fiscal Policy Actions " Federal Reserve Bank of St. Louis Working Paper No. 13 (January 31, 1971).

${ }^{10}$ Wicksell explained the natural interest rate as the rate "at which the demand for loan capital and the supply of sat: ings exactly agree." Knut Wicksell, Lectures on Political Economy, Vol. II Monety ed. Lionel Robbins (London: Rontledge \& Kegan Paul Ltd., 1935), p. 193.
}

credit permits firms to pay higher prices for factors of production, and they are able to bid resources away from consumers. The assumed shift in resources toward the production of more producer goods and fewer consumer goods leads to higher prices and a reduced supply of consumer goods. Many consumers, rather than pay the higher prices, choose to add to their savings - thus the term "forced" savings.

Sooner or later the banking system, taking note of inflationary pressures, cuts back its credit advances. Unless "new" saving is forthcoming, the market rate rises to the natural rate of interest, making investment projects, which appeared lucrative at the old, lower rate of interest, no longer profitable. The prices of consumer products continue to advance due to the earlier supply reduction as well as to the fact that the uncompleted investment projects add nothing to the existing stock of consumer goods. Workers in the declining investment goods industries cannot be easily shifted to consumer goods industries; thus unemployment emerges in the face of rising price levels.

If one gets the impression that this argument is something other than iron-clad, then one is probably on the right track. Economists were intrigued and baffled by Hayek's logic throughout the decade of the 1930s. But since Hayek's price effect went the wrong way (up), contrary to the experience of the 1930s, the Hayekian view was set aside.

Sir John Hicks, also a Nobel Prize winner in Economics, recently made another attempt at interpreting Hayek's theory. Recognizing the irrelevance of Hayek's diagnosis to the conditions of the 1930 s, Hicks stated that, "because it was wrong then, it does not follow that it must always be wrong. It is possible that there may be conditions to which it is appropriate; and in these days (in 1967) one may not have to look very far before one finds them.

"It can happen that there is unemployment even while there is inflation." Hicks envisioned conditions in which unemployment would occur due to a decline in the marginal productivity of labor. If labor fails to accept a decline in real wages, which conld occur for any number of reasons, unemployment could arise in conjunction with rising price levels. The reason for the decline in real wages accompanying a fall in labor's marginal productivity might be disadvantageous shifts in foreign trade, the destruction of capital through war or political upheaval, or more rapid population growth.

11Hicks, Critical Essays, p. 214. Italics supplied. 
But it is by no means excluded that it should happen for Hayek's reason: in the aftermath of an attempted expansion, greater than the economy was able, or willing, to afford - so that it has beer abortive. If shortages develop from such a cause, prices will rise; ... there may be no rate of price-rise which will not be altogether explosive, unless so severe a hand is kept upon the monetary circulation that unemployment results. There may be rapid inflation; but if it is to be kept down to a finite rate of inflation, there must be unemployment. This is the Hayek 'slump'. To such conditions the Keynesian prescription is irrelevant, as irrelevant as Hayek's was in 1931.12

How might we interpret the Hicksian view of Hayek, with an eye toward explaining price-unemployment developments in the 1970s? First, it is clear that the economy was overstimulated for a number of years, begiming in the 1960s. Second, "shortages" of all sorts emerged in the 1970s. Third, there has been a sharp decline in real wages. Fourth, although monetary expansion and inflation continued through much of the 1970s, a firm enough hand was kept on the monetary controls that money supply growth dropped sharply in 1974. Fifth, unemployment has risen substantially.

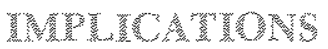

Obvious modifications must be made in Hayek's basic theory to explain current economic developments. Hayek's increases in bank credit, or money supply as some might say today, have not benefited private investment, but rather government, at the expense of consumers. If one takes the long view, it is striking that consumer spending as a percentage of GNP declined from 75 percent in 1929 to 63 percent in 1974 while government spending increased over that period from 8 percent to 22 percent. Investment, which was at 16 percent of GNP in 1929 , stood about unchanged at 15 percent in 1974 . If Hayek had foreseen in the 1930s this rapid growth of the government sector, he would undoubtedly not have waited so long to shift the emphasis of his theory of "slumps" from one which accentuated excessive business expansion to one which highlighted excessive government growth.

Another obvious change in Hayek's theory required to accommodate actual events is the necessity of introducing exogenous supply shifts. The "shortages" envisioned by Hayek occur entirely because of prior excessive demand. There is no doubt that rapid increases in demand on a worldwide scale the past

12lbid., p. 215. decade contributed strongly to the recent shortages of such items as food, oil, paper, and chemicals. However, it is necessary to note, especially in the case of fuels, that an important decrease in supply also occurred. One might attribute this to government wage and price controls, effective oligopolies, or to a disadvantageous shift in the terms of trade, as suggested by Hicks.

The above are probably the two most important changes required to update Hayek's views on unemployment and inflation. Given that we are still experiencing economic discomfort in both these areas, what policies would Hayek prescribe to alleviate the situation? First, he would probably remind us that we would never have gotten into our current difficulties if we had maintained a fairly steady, moderate growth rate of the money supply. In particular, we would have been better off not allocating increased credit to expand governmental operations.

Second, now that we have both considerable inflation and unemployment, we should not rely on driving the money supply in one direction or another in order to get out of this predicament; steady money growth to stabilize prices should be initiated. In addition, Hayek would undoubtedly advocate a reversal of the progressive growth of the government sector as a significant step toward the achievement of monetary stability.

Third, one might conjecture the remedies Hayek would endorse to include: 1) getting labor to accept a smaller real wage temporarily; and 2) increasing (over the longer run) the marginal productivity of labor. With regard to the former remedy, Hayek would likely suggest action to curb possible monopolistic practices of labor (he was also concemed about monopolistic business practices ). In addition, we should cut job information costs and reduce uncertainty by way of relying more strongly on the price signals emitted by a free market economy. With regard to the second remedy, Hayek would probably endorse policies directed toward maximizing labor effioiency through quantitative and qualitative improvements in the private capital stock.

What would Hayek's old rival Keynes suggest to alleviate our current economic discomfort? One might think that Keynes would turn toward vigorous government intervention in order to control unemployment and prices more closely. Keynes, however, was quite pragmatic in his approach to economic policymaking, as suggested by his change from a fairly or- 
thodox, neoclassical economist in the years preceding the 1930 s to an advocate of govermment action in the Great Depression. In his last conversation with Hayek, Keynes indicated that he adapted his economic ideas to fit the times. Hayek related the incident in the following passage:

Later a turn in the conversation made me [Hayek] ask him [Keynes] whether he was not concerned about what some of his disciples were making of his theories. After a not very complimentary remark about the persons concerned he proceeded to reassure me: those ideas had been badly needed at the time he had launched them. But I need not be alarmed: if they should ever become dangerous 1 could rely upon him that he would again quickly swing round public opinion - indicating by a quick movement of his hand how rapidly that would be done. But three months later he was dead. ${ }^{13}$

\section{SUly}

F. A. von Hayek was a man ahead of his time. Now living in, Austria, he wrote extensively of price and unemployment problems before switching later in life to political and social concerns. His earlier writings competed for attention with those of John Maynard Keynes. Keynes, whose analysis focused on unemploy-

13F. A. Hayek, Studies in Philosophy, Politics and Economics, (Chicago: The University of Chicago Press, 1967), p. 348 . ment issues, showed impeccable timing in his endorsement of the desirability of government intervention to escape from the throes of the Great Depression. Hayek, whose analysis incorporated both inflation and unemployment issues, was pushed into relative obscurity by the developments of the 1930s.

It is not yet clear exactly who has the best explanation for the economic events observed in the first half of the $1970 \mathrm{~s}$. There has been inflation at times, unemployment at times, and there have been times at which the two have occurred simultaneously. The Keynesian analytical framework, erected to explain unemployment deficiencies alone, would appear lack. ing. However, it is not obvious that the "forced saving" argument advanced by Hayek would be necessary or sufficient to explain our current problems. Possibly, Hayek's later theories, which interwove a concern for growing governmental control of resources and the money supply with a guarantee of full employment, are closer to the mark. His concern was that the inflationary tendencies inherent in these developments would eventually result in a pronounced change in the structure of capitalistic societies. In any event, the fact that Hayek foresaw many of the actual economic developments of the $1960 \mathrm{~s}$ and early $1970 \mathrm{~s}$ provides strong incentive for further study of his voluminous works.

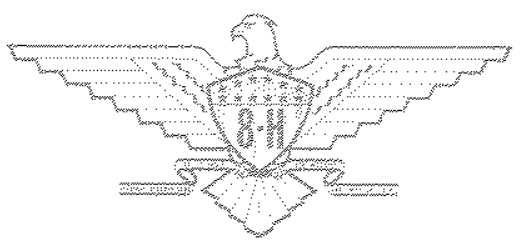

